\title{
A POESIA BRASILEIRA COMO TESTEMUNHO DA HISTÓRIA (RASTROS DE DOR, TRAÇOS DE HUMOR): A EXEMPLO DE CHACAL
}

\author{
THE BRAZILIAN POETRY AS A WITNESS OF HISTORY (TRACES OF \\ PAIN, TRACES OF HUMOR): LIKE CHACAL
}

Wilberth SALGUEIRO ${ }^{15}$

\begin{abstract}
RESUMO: A proposta da pesquisa é estender o conceito de testemunho na literatura, estudando-o à luz da produção poética brasileira das últimas décadas. A tendência preponderante dos estudos acerca do testemunho é a de perpetuação do sofrimento, gerando, com frequência, um radical ressentimento. Pensamos reler esta poesia, explorando o conhecido traço humorístico que atravessa, sobretudo, o período setentista: dor que, às vezes, vira humor que dela se apropria para produzir a reflexão via poema. Poema dorido, sim, para não esquecer; mas humorado também, para não se render de todo ao trauma. Em pauta, poemas de Paulo Leminski, Leila Míccolis, Glauco Mattoso e, sobretudo, de Chacal.
\end{abstract}

PALAVRAS-CHAVE: Poesia brasileira contemporânea; Testemunho; Dor e humor.

\begin{abstract}
The aim of the research is to stretch the concept of testimony in literature, studying it under the light of the Brazilian poetic production over the last decades. The main tendency of the studies about testimony is to perpetuate suffering, thus frequently generating a radical resentment. We intend to read this poetry exploring the well-known humorous mark which crosses the seventies, in especial: pain that, sometimes, becomes humor which takes it to produce reflexion via poem. Hurtful poems, yes, in order not to forget; but wellhumored, as well, for not surrendering to trauma. We focus poems by Paulo Leminski, Leila Míccolis, Glauco Mattoso and, especially, Chacal.
\end{abstract}

KEYWORDS: Brazilian contemporary poetry; Testimony; Pain and humor.

\footnotetext{
${ }^{15}$ Bolsista CNPq / Departamento de Línguas e Letras. Programa de Pós-Graduação em Letras Universidade Federal do Espírito Santo (UFES) - CEP 29075-910 - Vitória - ES - Brasil - E-mail: wilberthcfs@gmail.com
} 
A ideia básica é ampliar (mas simultaneamente delimitar) o conceito de testemunho na literatura, estudando-o à luz da produção poética brasileira das últimas décadas. Trata-se, pois, de uma nova proposta de testemunho - seja em período ditatorial, seja democrático - que a poesia pode nos ofertar: como lidar com a dor, no sentido existencial mais lato, de forma concomitantemente humorada e não alienada politicamente. Numa palavra: poesia crítica, que ri de si e, assim, de seu muitas vezes triste e trágico entorno.

A noção fundadora, e sem dúvida mais ortodoxa, de testemunho, vem da chamada "literatura do Holocausto", emblematizada pelos relatos de sobreviventes da Segunda Guerra Mundial. Dentre esses relatos, sobressaem-se a contundente narrativa de Primo Levi e a densa poesia de Paul Celan, tendo ambos os autores se suicidado décadas depois (em 1987 e 1970, respectivamente) do final da guerra de 1945. Na América Latina, ganhou significativo relevo a sofrida história da índia e camponesa guatemalteca Rigoberta Menchú, Nobel da Paz em 1992, cujo depoimento foi transcrito e editado pela antropóloga venezuelana Elizabeth Burgos.

Aqui no Brasil, a ditadura militar que principia com o golpe de 64 inspirou, a contrapelo, toda uma produção que, baralhando memória e ficção, registrou as agruras deste período plúmbeo, cujos tons começaram a suavizar apenas a partir de 1979, com o fim oficial em 31/12/1978 do AI-5 decretado em 13/12/1968. Bastante representativo desta vertente é o livro $O$ que é isso, companheiro?, do então jornalista Fernando Gabeira. Retroagindo-se no tempo, poder-se-ia elencar como exemplo de prosa de testemunho as Memórias do cárcere, de Graciliano Ramos; e, ao contrário, em direção ao nosso presente pretensamente mais justo e democrático exemplos de textos com "teor testemunhal" (para recuperar sucinta e precisa expressão cara a Márcio Seligmann-Silva) seriam Capão pecado, de Ferréz, ou, ainda, Estação Carandiru, de Dráuzio Varella, e mesmo Cidade de Deus, de Paulo Lins.

Nos estudos, cada vez mais numerosos, que se destinam a investigar as relações entre "testemunho e literatura no Brasil", é nítida a escassez de pesquisas que relacionam "testemunho e poesia". Num dos mais importantes livros, no Brasil, sobre o assunto - História, memória, literatura - o Testemunho na Era das Catástrofes 
(SELIGMANN-SILVA, 2003), nenhum dos dezoito textos aborda a poesia brasileira (há, aqui e ali, alusões à poesia de Paul Celan, já um cânone quando se fala em testemunho; e o excelente artigo “As 'crianças' de Alterman”, de Nancy Rozenchan). Os motivos desta flagrante ausência se explicam basicamente por dois fatores: 1) a força da narrativa brasileira (autobiográfica ou não) de testemunho, que, sobretudo via alegoria, perscrutou as entranhas das máquinas de poder e extermínio de nosso governo ditatorial (DALCASTAGNÈ, 1996); 2) a peculiaridade do discurso lírico, que, altamente subjetivo, iria de encontro ao pressuposto básico do testemunho, ou seja, o grau de cumplicidade entre (a) aquele que fala - a testemunha e/ou sobrevivente; (b) aquilo de que se fala - a violência, a catástrofe, o evento-limite; e (c) a coletividade representada - vítimas e oprimidos.

Parece hegemônica, ainda, a perspectiva de que o tal "eu lírico" (a própria expressão induz à categoria da subjetividade plena) não enxergaria muito longe além da particular vivência, sendo incapaz - por excelência, desde o seu estatuto de gênero - de falar do outro, a não ser de forma interessadamente solipsista. Quando muito, o outro constituiria uma espécie de máscara do sujeito. A história e o mundo seriam como que filtrados pela experiência daquele que, em verso (ou nalgum suporte alternativo), se exprimiria, resultando, ao fim e ao cabo, um registro em que a marca da individualidade se mostraria incontornável. Ademais, a exuberância da linguagem poética, carregada de efeitos lúdicos e muitas vezes autotélica, contribuiria para o inequívoco distanciamento entre, diria Adorno, "lírica e sociedade". Por fim, registre-se ainda o estigma negativo que certa "lírica engajada" carrega, ao querer se atribuir uma função social transformadora, relegando a segundo plano o próprio da arte literária que é seu labor estético.

Não é de tal modo, em absoluto, que esta pesquisa entende o lugar e o funcionamento da voz lírica. Em clássico artigo de 1957, Adorno pensava as relações funcionais entre lírica e sociedade, entre sujeito e coletivo, entre forma e história, num mundo desencantado, pós-guerra. Redimensionando radicalmente estas relações, o filósofo alemão diz que

[...] o eu que ganha voz na lírica é um eu que se determina e se exprime como oposto ao coletivo, à objetividade. [...] $\mathrm{O}$ autoesquecimento do sujeito, que se entrega à linguagem como a 
algo objetivo, é o mesmo que o caráter imediato e involuntário de sua expressão: assim a linguagem estabelece a mediação entre lírica e sociedade no que há de mais intrínseco. Por isso, a lírica se mostra mais profundamente assegurada, em termos sociais, ali onde não fala conforme o gosto da sociedade, ali onde não comunica nada, mas sim onde o sujeito, alcançando a expressão feliz, chega a uma sintonia com a própria linguagem, seguindo o caminho que ela mesma gostaria de seguir. (ADORNO, 2003, p.70 e 74).

Este momento em que o sujeito, taticamente, se impõe - se opondo - sobre o momento histórico (coletivo, objetivo) constitui o que Adorno denominou de "fratura": nem resistência-engajamento, nem paródia-sátira, o poema fratura e dilui o que dele se poderia esperar como cumplicidade social e crítica política. Impera o exercício da linguagem que de dentro se constrói, não se constrói para fora.

Um outro diferencial do projeto em pauta reside na equação, sempre delicada e complexa, entre dor e humor. A tendência preponderante dos estudos de testemunho na literatura brasileira é a de perpetuação do sofrimento, provocado em grande parte pelo autoritarismo atroz dos dirigentes truculentos e mesmo fascistas de nosso Estado. O sofrimento leva, com frequência, ao ressentimento (às vezes travestido de atitude politicamente engajada). Pensamos reler a poesia, agora, explorando o conhecido traço humorístico que atravessa todo esse período - em especial da poesia dita marginal mas de modo dialético: dor que gera humor que dela se apropria para produzir a reflexão via poema. Dorido, sim, para não esquecer, mas humorado também, para não se render de todo ao trauma.

Para além de se fixar no período recortado entre o golpe e a anistia, os tenebrosos anos que vão de 1964 a 79, a proposta é igualmente ver como a poesia se comporta em épocas politicamente democráticas. A grande dor coletiva de uma nação silenciada pela ditadura dá lugar a uma explosão de outros infortúnios, também coletivos, que se deixam ver e ouvir na lírica mais recente: a poesia é brasileira, sim, mas os problemas que a atravessam também atravessam as tênues fronteiras nacionais.

Tenho estudado certas obras poéticas à luz dessas questões. Para dar uma dimensão do estado das reflexões acerca do tema, resumo algumas dessas análises. Em Leila Míccolis, por exemplo, dediquei-me à exposição e problematização de aspectos da 
categoria "literatura de testemunho", buscando entender a contundência da produção poética brasileira pós-1964 em poemas como "Carreiras" [1980]: “Os que ficam lá no Norte / morrem crendo: se viessem / melhorariam de sorte. / Muitos caem pela estrada / sem enterro, sem jazigo; / mas os mais afortunados / chegam... ao posto de mendigo." (O bom filho a casa torra, 1992).

Para ler Glauco Mattoso, parti de um ensaio de 1974 de Hans Magnus Enzensberger em que se fala do "efeito aspirina" da literatura (ela se dissolve, mas não desaparece) e do supracitado ensaio de Adorno em que se fala de uma "corrente subterrânea coletiva", vendo na forma lírica, além da expressão individual, a inscrição da experiência histórica. De 1977 a 1981, as 53 "folhas soltas" do Jornal Dobrabil testemunharam um tempo de transição. A carnavalização "apolineobarroca" e "arcadionisíaca" de Glauco Mattoso dos "dactylogrammas" de então se mantém nos cáusticos sonetos da antologia Poética na política (cem sonetos panfletários), de 2004. Mesmo em contexto democrático, continua o tom cético e a verve demolidora do artista, fazendo de sua própria obra um exemplo da "corrente coletiva" que se sustenta na contramão do império dos meios de comunicação de massa, ainda que pelos resíduos marginais, não midiáticos, da literatura. Em poemas como "Hino patriótico do prisioneiro político" [1977] - "independen / te / men / te /// de quem / te / men / te /// tens o de / ver / de /// outra ver / dade de / fender" (Jornal Dobrabil, 2001) -, pode-se discutir a presença, no cenário contemporâneo da cultura brasileira, de vícios e mazelas oriundos do regime militar ditatorial.

Um terceiro e breve exemplo de como a pesquisa tem procedido pode ser verificado na comparação de três poemas - "Dia da partida" (Inventário de cicatrizes, 1978), de Alex Polari; "ameixas / ame-as / ou deixe-as" (Não fosse isso e era menos / Não fosse tanto e era quase, 1980), de Paulo Leminski; e “Água virgem” [1968] (Inéditos e dispersos, 1985), de Ana Cristina Cesar - em que se procurou pensar os modos plurais de apreensão estética do contexto histórico, tomando como parâmetro o Brasil ditatorial pós-golpe militar. O poema de Leminski pede, de imediato, um despojar-se da grandiloquência, ao colocar chistosamente num pedestal algo tão sem importância, digamos, vital: ameixas. Para provocar um tal estranhamento, o chiste bastaria, com seus efeitos de condensação e deslocamento. Visível é o recurso de tirar de uma palavra outra palavra ("ame" + "as", e "eix" + "as" de "ameixas"), que o poeta 
num estudo sobre Bashô e o haicai denominou kakekotoba: "É a passagem de uma palavra por dentro de outra palavra, nela deixando seu perfume. Sua lembrança. Sua saudade" (LEMINSKI, 1990, p.93). O leitor há de se lembrar ou de descobrir - no inexorável processo de decodificação para o deleite estético - tratar-se o poema de uma bem-humorada paródia sobre os negros anos da ditadura, quando o governo militar divulgou por todos os rincões o slogan "Brasil: ame-o ou deixe-o", que nutriu de ilusão e má-fé toda uma geração de ingênuos e desinformados. Reduzido, por analogia, a uma ameixa, o país se perde na plenipotência da arrogância e da propaganda enganosa, ao produzir retoricamente um discurso midiático de acusação, chamando os exilados (e, por extensão, os presos e assassinados pelo regime) de "traidores" e "subversivos". É o tipo de poema que nos incita a rever a memória pátria, sem ufanismos tolos ou xenofobias tacanhas ${ }^{16}$.

Muitos, hoje, constituem os estudos acerca da literatura de testemunho, no mundo. Entre nós, o livro Catástrofe e representação resulta uma fundamental fonte para a pesquisa sobre o assunto. Abre a obra o longo e excelente texto "Educação e crise, ou as vicissitudes do ensinar", de Shoshana Felman (2000). Remetendo à célebre ideia de Adorno, Felman (2000, p.47) afirma que se pode pensar a poesia de Celan como "resistência criativa e autocrítica ao veredito de que, desde então [depois de Auschwitz], é um ato de barbárie escrever lírica e poeticamente". Se o nazismo queria o nivelamento, o apagamento, o aniquilamento, a indiferenciação total dos seres feitos meros números, ter sobrevivido e testemunhar significa "engajar-se no processo de reencontrar seu nome próprio, sua assinatura" (p.64) - para si e também para singularizar o nome dos que não sobreviveram. A lição do ensaio é que ensinar deve se assemelhar ao testemunhar, no sentido de "fazer algo acontecer, e não apenas transmitir um conhecimento passivo" (p.67), para que assim se possa perceber o dissonante e não somente o congruente. Todo esse itinerário que Shoshana Felman nos faz percorrer, com ela, possui um sentido maior: a celebração da vida em sua irredutível diferença.

Na mesma coletânea, Catástrofe e representação, há de Márcio Seligmann-Silva o ensaio "A história como trauma" (2000). Retorna-se, com mediações, ao conceito

\footnotetext{
${ }^{16}$ Análises mais detidas dos poemas citados nos três exemplos se encontram no livro Lira à brasileira: erótica, poética, política (SALGUEIRO, 2007).
} 
kantiano de "sublime", para apontar a complexidade entre o que deve ser descrito (de dimensão ética e histórica), mas que não se alcança (de dimensão estética e metafísica). Via Freud, a noção de trauma como "uma ferida na memória (...) problematiza a possibilidade de um acesso direto ao "real"” (p.85) - mas o recurso à metáfora, mais uma vez, põe em xeque "o conflito entre a necessidade e a impossibilidade de representação" (p.90) do evento catastrófico, dado seu excesso de realidade.

Valéria de Marco no artigo "A literatura de testemunho e a violência de Estado" (2004) destaca a estreita fronteira estabelecida entre este estudo e os ditos estudos culturais, a partir, sobretudo, do exame da violência das ditaduras da América Latina no século XX. Faz um levantamento das principais questões teóricas e históricas, retomando as categorias de catástrofe, indizibilidade, trauma e sublime, e trazendo algumas formulações já conhecidas de Adorno, Levi e Celan. A literatura de testemunho deve ter densidade, profundidade, qualidade literária, durabilidade, fidelidade aos fatos, conhecimento do evento, relevância para o contexto. Percebe-se que a avassaladora existência da "literatura de testemunho", na sua salutar diversidade conceitual, promove um inevitável abalo na noção de cânone e de valor literário, além de alterar o quadro dos agentes ou produtores de literatura: textos e registros de presos, torturados, crianças de rua, favelados, empregados domésticos, doentes terminais, índios, enfim, todo um grupo "subalterno" que agora depõe e se expõe não só em nome próprio, mas também em nome de muitos.

Para Jeanne Marie Gagnebin, nos textos de testemunho a "vontade ética" parece compensar alguma fragilidade formal (2000). Essa tensão entre irrepresentabilidade estética e necessidade ética é, a todo momento, fixada nos estudos de Seligmann sobre a literatura de testemunho, cuja existência (e resistência), conforme conclui Shoshana Felman, pode modificar nossa postura diante da prática do ensino: algo deve se transformar, "acontecer".

Os estudos sobre o riso, a ironia, o chiste, a comicidade, o humor, a comédia e inúmeros termos afins passam da ordem do quantificável (de Aristóteles a Umberto Eco, por exemplo) e não pertencem, exclusivamente, a nenhum campo de saber específico. A filosofia, a sociologia, a psicologia, a história, a antropologia, a medicina e a literatura mostram-se recheadas de textos sobre o humor. Assim, não sendo esta uma 
pesquisa psicossociológica do tema, sigo o mesmo critério adotado por Benedito Nunes em seu artigo "O riso modernista", em que considera

[...] o humorístico no sentido lato, compreendendo a verve do chiste, da piada, da anedota, da paródia, e das várias espécies do cômico - o burlesco, o bufo, o grotesco, ora carregado na ironia e no sarcasmo, ora apresentando o mesquinho e o ridículo, ora satirizando, ora intensificando o contraste até o absurdo - o que seria o humorismo propriamente dito, como uma atitude complexa em face do mundo. (NUNES, 1993, p. 29).

Freud, no início de Os chistes e sua relação com o inconsciente, de 1905, rastreia o conceito de chiste em alguns pensadores da época: "Um chiste é um juízo lúdico" (Fischer); "A brevidade é o corpo e a alma do chiste, sua própria essência" (Jean Paul); "Um chiste diz o que tem a dizer, nem sempre em poucas palavras, mas sempre em palavras poucas demais, isto é, em palavras que são insuficientes do ponto de vista da estrita lógica ou dos modos usuais de expressão" (Lipps). Dissociando o chiste do cômico, Freud detecta que "rimas, aliterações, refrães, e as outras maneiras de repetição de sons verbais que ocorrem em versos, utilizam a mesma fonte de prazer - a redescoberta de algo familiar" (FREUD, 1977, p.144). Daí, resume os recursos de que lança mão a condensação típica do chiste (e que encontra correspondência também nos sonhos): uso múltiplo do mesmo material, jogo de palavras, e similaridade fônica. Dito de diverso modo, o prazer provocado pelo chiste possui um núcleo verbal e um outro no nonsense.

Humor não é riso, muito menos gargalhada. Em "O riso, o cômico e o lúdico", Eduardo Menezes analisa as nuances diferenciais desses termos e afirma que a intolerância deriva do esprit géométrique, ao passo que o riso e o cômico originam-se do esprit de finesse (1974, p.10). Menezes destaca a dificuldade de operacionalizar conceitos tão flutuantes e congeniais ao comportamento humano, recorda a assertiva de Kant - a causa do riso está na súbita redução de uma expectativa intensa a nada - e sintetiza a tríade conceitual na qual se baseou Freud: o chiste - gracejos, piadas, anedotas, trocadilhos - provoca o riso por meio de um jogo de palavras ou ideias; o cômico, por sua vez, refere-se a eventos ou objetos lúdicos, gozados, alegres, ridículos 
etc., e envolve a percepção de alguma espécie de contraste; já o humor se reserva para os casos em que uma pessoa dá pouca importância a seus infortúnios e está apta a ver o seu lado engraçado.

De $O$ riso de Henri Bergson (1983, p.15 e p.18), relembremos uma definição:

O risível é certa rigidez mecânica onde deveria haver maleabilidade atenta e a flexibilidade viva de uma pessoa. [...] O que a vida e a sociedade exigem de cada um de nós é certa atenção constantemente desperta, que vislumbre os contornos de uma situação presente, e também certa elasticidade de corpo e de espírito, que permitam adaptar-nos a ela.

Bergson vai ressaltar igualmente o caráter social e destronador do riso.

Desde Aristóteles (1984), há uma nítida distinção entre o sério e o ridículo. Já dizia o Estagirita que a comédia era imitação da ação de homens inferiores; não, todavia, quanto a toda espécie de vícios, mas só quanto àquela parte do torpe que é ridículo. O ridículo é apenas certo defeito, torpeza anódina e inocente. Para a tragédia reservam-se as ações e os caracteres elevados, nobres; o que for baixo, vil, plebeu, grotesco - isso fica para a comédia. Decerto, passados quase dois milênios e meio, a ideologia da seriedade ainda impera em termos conjunturais. É o que nos afirma o antropólogo Luiz Felipe Baêta Neves (1974, p.36):

A ideologia da seriedade impõe uma antinomia absoluta entre seriedade e comicidade, qualifica positivamente a primeira e, subsequientemente, identifica seriedade e saber. Confunde arrogância e sisudez com seriedade e responsabilidade para melhor recalcar o poder corrosivo e libertador que a comicidade pode carregar.

A tarefa promissora a que uma antiideologia da seriedade deveria se propor seria a de procurar definir um conceito do cômico como uma totalidade em que fosse considerada a comicidade como forma específica de conhecimento do social e, ainda mais, como forma renegada e estigmatizada de leitura crítica da opressão. Um conceito, enfim, que negue a antinomia rir/pensar e abra caminho para a introdução da comicidade no repertório de temas passíveis de serem estudados cientificamente.

É próprio do humor não se deixar aprisionar por nenhum discurso específico. Freud, no final do seu estudo, compara as técnicas do chiste com as do sonho. Bergson vê no riso uma proeminente função social. Propp conclui ser inexequível subdividir o 
cômico em vulgar ou elevado e igualmente impossível definir aprioristicamente se a comicidade é um fenômeno extra-estético (1992, p.78). Se recorremos aos conhecidos estudos de Bakhtin (1999), encontramos a diferença entre riso e seriedade: esta é monológica, disciplinada, sedentária e sistêmica; aquele é dialógico, irrequieto, nômade e anárquico. Para Nietzsche (1995), tanto quanto "jogar" e "dançar”, "rir" constitui um gesto de autonomia do pensamento. O poeta W. H. Auden, em artigo intitulado "Notas sobre o cômico”, utiliza uma epígrafe de Lichtenberg (1993, p. 285) que aqui calha bem: "A melhor maneira de se conhecer o caráter de uma pessoa é examinar a natureza da brincadeira que a mesma levou a sério".

Enfim, são tantos os modos de abordagem e as nomenclaturas relativas ao humor que qualquer tentativa de homogeneização do conceito redundaria em redução. Feito um phármakon, o humor corrói e/ou ratifica aquilo sobre o que - a depender da dose se lança.

Para que se avalie o rendimento desta perspectiva - ou seja, de analisar poemas que incorporem dor e humor a um só tempo - façamos uma leitura do poema "Como é bom ser um camaleão", de Muito prazer, Ricardo, de 1971, primeiro dos 13 livros de Chacal, publicado sob a sombra do governo do general Médici.

A metáfora do poeta (ser um camaleão) retorna, coincidentemente, no artigo “Alice e o camaleão”, de Elio Gaspari, em 2000: se lá, no poema, o bicho designa o poeta sobrevivendo, aqui, no texto do jornalista, representa as metamorfoses estratégicas pelas quais passou a ditadura brasileira. Quando, ao fim de seu livro de estreia, Chacal agradece "a tensão dispensada", está pondo em relevo a difícil arte de fazer poesia, jovem, bem-humorada, viajante, desbundada - em tempos de horror: repressão, tortura e morte. A análise particular do poema há de apontar possíveis conexões entre os discursos da poesia e da história.

Carioca da Zona Sul do Rio de Janeiro, Chacal vem militando - literalmente na praia da poesia. Impressiona a homogênea toada, batida, dicção que o poeta perpetua desde 1971, aos 20 anos, com Muito prazer, Ricardo, até seu recente Belvedere (2007), reunião de toda a obra, com inéditos. Daqui, de hoje, do belo e verde livro de capa dura, para "que você, leitor, possa se alimentar e se divertir, possa ler, ver e ouvir" (CHACAL, 2007, p.7), o poeta cinquentão mira o marginal de outrora, dizendo, também numa espécie de "apresentação", para "corações apaixonados" (a quem dedica 
o livro inaugural): "essas são as coisas que eu faço com prazer / achei que você podia saber e brincar / com elas. / taî" (CHACAL, 1997, p.5). Mais adiante, pode-se ler: "Na primeira edição do Muito prazer [1971], por paranóia ou não, fui aconselhado a assinar Ricardo, meu nome cristão. Assim era a capa: Muito prazer, Ricardo. Hoje as coisas aparentemente mudaram" (p.10).

Quem transita pela poesia brasileira contemporânea pode, algum dia, ter ouvido alguns desses versos de Ricardo de Carvalho Duarte, o Chacal: "Prezado cidadão": “colabore com a lei / colabore com a Light / mantenha luz própria” (Muito prazer, Ricardo, 1971); "Falô": "até que um dia / pisaram o pé dele. / orlando tirou a identidade do bolso / e disse: / — pra vocês basta isso de mim. / foi embora assoviando /// a palavra ilegal afinal (Preço da passagem, 1972); "Papo pop": "vamos bater um papinho / bem popinho / vamos bater um pozinho" (Nariz aniz, 1979); "É proibido pisar na grama": "O jeito é deitar e rolar." (Boca roxa, 1979); "Bermuda larga": "muitos lutam por uma causa justa / eu prefiro uma bermuda larga / só quero o que não me encha o saco / luto pelas pedras fora do sapato" (Comício de tudo, 1986).

Décadas depois da estreia, o tom se mantém: o prazer dos intensos anos 70 se estende à bela vista dos anos 2000. Estampa-se um nítido projeto de poesia como deleite, gozo, divertimento, celebração. Será, no entanto, que, em pleno regime militar ditatorial, os versos do poeta se postaram a distância das intempéries políticas? E se esta distância for mais uma tática - um tipo de resistência? Terá sido tal procedimento uma opção do autor em pauta ou um modo estético geracional? Por fim, como o desbunde contracultural - supostamente à margem tanto de valores ideológicos burgueses, caretas e conservadores, quanto de atitudes típicas de um radical engajamento, bélicas e utópicas - expressou a história de seu tempo? Estas e outras perguntas podem nos fazer entender mais que um poema, um livro ou a obra de um poeta (o que não seria pouco).

Tomando a trajetória de Chacal como modelar de um certo tipo de pensar e criar poesia, partamos de um poema de Muito prazer, Ricardo, para, em torno dele, desfiar considerações:

como é bom ser um camaleão

quando o sol está muito forte, como é bom ser um camaleão

e ficar em cima de uma pedra espiando o mundo. 
se sinto fome, pego um inseto qualquer

com minha língua comprida.

se o inimigo espreita, me finjo de pedra

verde, cinza ou marrom.

e, quando de tardinha o sol esfria,

dou um rolê por aí

(CHACAL, 1997, p.25).

O poema, com 9 versos de 6 a 14 sílabas métricas e ocasionais rimas toantes, prima pela coloquialidade, cujo ápice acontece no derradeiro verso, com a informal expressão "dar um rolé" - isto é, dar uma volta, um passeio - ganhando uma versão sonoramente fechada, "rolê". De resto, trata-se de um texto bem à moda marginal, em que o pequeno afronta o monumento, o cotidiano impõe-se como topos, o prosaico lirismo se faz com pitadas de pueril inocência, sem lances de engenhosas elipses nem visíveis cálculos para os olhos do incauto leitor.

A singela fábula fala de um camaleão, que, curioso, fica a espiar o mundo; faminto, usa a "língua comprida" para saciar-se; acuado, usa sua arma cromática e se disfarça; curioso e precavido, longe o inimigo, sai "por aí", livre, lépido e fagueiro. Tentando entender até que ponto um texto resiste às investidas vampirescas do teórico que dele se alimenta, Barthes (1977, p.50) escreveu:

Se você mete um prego na madeira, a madeira resiste diferentemente conforme o lugar em que é atacada: diz-se que a madeira não é isotrópica. O texto tampouco é isotrópico: as margens, a fenda, são imprevisíveis. Do mesmo modo que a física (atual) precisa ajustar-se ao caráter não-isotrópico de certos meios, de certos universos, assim é necessário que a análise estrutural (a semiologia) reconheça as menores resistências do texto, o desenho irregular de seus veios.

Trocando em miúdos: não exijamos de um texto aquilo que ele não quer, ou não pode, nos dar. Chacal não é Cabral.

O que o poema, queira ou não, sempre nos faz ver é o tempo em que acontece. Para tanto, não precisa ser engajado, nem explicitar marcas de qualquer ideologia, tampouco funcionar feito um panfleto distribuído em via pública. Qualquer poema já traz - sob a forma de pílulas homeopáticas contidas no recipiente maior do livro - todos os traços na linguagem mesma em que se mostra: o vocabulário, o corte dos versos, um certo jargão e, sobretudo neste exemplar, a pitada alegórica que dele se desentranha. É 
pela via alegórica que o ingênuo poema de Chacal ganha alguma densidade e sai do lugar de mera piada para ocupar outro posto: o de espia do mundo.

O mundo que o poema (o camaleão, o poeta) espia é o Brasil militarizado, sob a égide de generais, arenas, dops, doi-codis, sni's. Amedrontados, os cidadãos, em especial nos contextos urbanos, viviam tensos, à flor da pele, na corda bamba: estávamos, em 1971, no auge da belicosidade do governo de Garrastazu Médici, que, então,

[...] não se limitou à repressão. Distinguiu claramente entre um setor significativo mas minoritário da sociedade, adversário do regime, e a massa da população que vivia um dia-a-dia aceitável nesses anos de prosperidade econômica. A repressão se dirigiu ao primeiro grupo, enquanto a propaganda se destinou a pelo menos neutralizar o segundo. (FAUSTO, 2002, p.267).

Conjunturas econômicas bem favoráveis explicam, sem que nenhuma fé transcendental seja invocada, o propagado milagre de Delfim. O que pouco se propagou foi que este aparente milagre estava, na verdade, concentrando renda e acumulando capital para os do topo da pirâmide, enquanto, cá em baixo, a população trabalhadora e a classe média mal se davam conta da crescente perda de poder aquisitivo e do incrível aumento das desigualdades sociais:

Outro aspecto negativo do 'milagre', que perdurou depois dele, foi a desproporção entre o avanço econômico e o retardamento ou mesmo o abandono dos programas sociais pelo Estado. O Brasil iria notabilizarse no contexto mundial por uma posição relativamente destacada pelo seu potencial industrial e por indicadores muito baixos de saúde, educação, habitação, que medem a qualidade de vida de um povo. (FAUSTO, 2002, p.267).

Se, na economia, o país se mascarava próspero, na condução política o regime se fazia de chumbo. Quem imaginaria, em 1971, os rumos do Estado brasileiro? Que ventos levariam o país - e para onde?

Elio Gaspari, no artigo "Alice e o camaleão", aponta instigantes hipóteses de leitura, partindo da notícia dada pelo Jornal do Brasil no dia 31 de dezembro de 1978: "Regime do AI-5 acaba à meia-noite de hoje". O baixo impacto da notícia deveu-se ao fato de ser aquela uma "morte anunciada": desde outubro de 1978 uma emenda 
constitucional já decretara o fim do famigerado AI-5. Mas mais que um desinteresse ideológico coletivo - que a paulatina normalização democrática teria se encarregado de nutrir - o que ocorreu foi que o regime ditatorial iniciado em abril de 1964 "foi desmontado aos poucos, com tamanha precisão que até hoje não se pode dizer quando acabou. Talvez o certo seja dizer que não foi desmontado. Foi camaleonicamente transformado" (GASPARI, 2000, p.12). A precisão do processo, sob a capa da pacificação civil do país, garantiria a segurança e a imunidade dos "camaleões fardados".

Episódios como (a) a posse de Tancredo Neves, e a seguir a de Sarney, em 1985; (b) a demissão de um general quatro estrelas (Ednardo d'Avilla Mello) responsabilizado pela morte do metalúrgico Manuel Fiel Filho, em 1976; (c) a demissão do general linhadura Silvio Frota, em 1977; e (d) a Constituição Cidadã, de 1988, são tomados por Gaspari como emblemáticos de momentos em que o "conceito" pleno de ditadura, de fato, se vê abalado. A prevista (e) revogação do AI-5, em 31/12/78, seria o corolário de um processo de metamorfose que o regime autoritário, camaleônico, se impôs, governo a governo. Da tomada do poder, em 64, ao endurecimento de 69-73 (Médici), passando pela distensão de 74-78 (Geisel) e pela abertura de 79-84 (Figueiredo), até chegar aos civis Tancredo e Sarney (85-89) e à esperada eleição direta de Collor (90-92), o Brasil foi sendo pintado por cores as mais distintas. No período mais negro desse arco multicromático estava nosso poeta, Chacal, em 1971, lançando mão, então, da mesma imagem - mas para fim diverso - do camaleão. O livro, apesar dos pesares, chamava-se Muito prazer, Ricardo. Do livro, o próprio autor vai comentar, com algum humor triste, na reedição de 1997:

[...] no verão de 72, Hendrix, Joplin, Jim Morrison, Brian Jones já viam, desmedidos, a grama crescer pela raiz. As flores no cabelo murchavam e Lennon desacordava do sonho. No Brasil, a Lei do Cão vigorava. Tortura e morte eram a ordem do dia. A juventude variava entre a luta armada e o trio elétrico. Pela sete, Torquato Neto desgovernava a navilouca, acendendo o gás. Da ECO, no Campo de Santana ao Píer em Ipanema eu fazia circular 100 cópias mimeografadas desse Muito prazer. Era o primeiro torpedo, meu cartão de visita. (CHACAL, 1997, p.9).

O futuro bacharel em Comunicação (pela UFRJ, em 77) certamente não desconhecia as agruras - políticas, econômicas, culturais - pelas quais passava o país. 
Nem então, nem depois, sua poesia egóica quis servir. Orlando Tacapau, de Preço da passagem (1972), talvez se horrorizasse ao ouvir autotelismo, intransitividade, finalidade sem fim, estética kantiana etc. A revolução, para a tribo e a trip de Chacal, era a vida, o corpo, o movimento. No píer, nas dunas da Gal, na ilha do Posto 9, sem patrulhas, a ordem do dia indicava: "Rápido e rasteiro": "vai ter uma festa / que eu vou dançar / até o sapato pedir pra parar. /// aí eu paro / tiro o sapato / e danço o resto da vida" (CHACAL, 1997, p.27) ${ }^{17}$.

A sutil ambiguidade do segundo "dançar" - que, além do dionisíaco "bailar", permite os carregados sentidos de "sair-se mal", "ser preso", "ser morto" - deste poema nos faz retornar ao outro, "como é bom ser um camaleão".

Feito um breve périplo pela nossa história (com ares de "história antiga" para as novas gerações), podemos afirmar que o camaleão de Chacal, com todos os trocadilhos, é um animal político. Para sobreviver, se camufla: ora se protege das forças naturais (sol e fome), ora se esconde do "inimigo [que] espreita" (medo e terror); quando as condições favorecem, curte a liberdade de ir e vir. Chacal nem adere ao discurso do milagre nem se engaja na luta armada. Seu barato, seu desbunde, sem culpa, é o prazer, o muito prazer juvenil do sexo, drogas e rock-'n'-roll. O “inimigo” do poema bem pode ser a "ditadura" e seus tentáculos: censura, repressão, torturas, assassinatos - mas também, sem dúvida, o "inimigo" é a caretice, a chatice, o sistema, a burguesia, as instituições, "anel de grau, hipocrisia, paletó e gravata, carreirismo, eficiência, prepotência, dinheiro no banco" (CACASO, 1997, p.35) etc. Antes, neste preciso ensaio, Cacaso já dissera: "A poesia de Chacal é uma poesia da carência e da precariedade; é isso que sua utopia do descompromisso e da pureza está querendo dizer, e é também isso que explica seu conteúdo ético e normativo. Chacal pratica e propõe uma poética da ética" (p.27).

No poemão marginal, escrito nos setenta, tem de tudo um muito: desde poemas e poéticas mais programaticamente vinculados a questões de ordem ideológica ou mesmo de ordem estética (herdeiros cepecistas ou vanguardistas - ver HOLLANDA, 1992), até, antípodas, obras que sem-cerimônia se fizeram ao sabor do miúdo, do rolê, do

\footnotetext{
${ }^{17}$ Este poema entrou na antologia Os cem melhores contos brasileiros do século, com organização de Ítalo Moriconi.
} 
improviso, do relaxo, do gesto, da viagem, do desbunde, do assistemático. Obviamente, neste poemão e em cada um de seus polimétricos versos estão incorporados, siameses, valores estéticos e ideológicos.

Cabe, creio, a certa crítica brasileira olhar, sem benevolência mas com instrumentos apropriados, e ver que os referidos valores estão em todo lugar, lá em Mallarmé e em Manoel de Barros, em João Cabral e em John Lennon ${ }^{18}$. Categórico e generoso, em já clássico texto, Benjamin (1983, p.223) dirá:

\begin{abstract}
A luta de classes, que um historiador educado por Marx jamais perde de vista, é uma luta pelas coisas brutas e materiais, sem as quais não existem as refinadas e espirituais. Mas na luta de classes essas coisas espirituais não podem ser representadas como despojos atribuídos ao vencedor. Elas se manifestam nessa luta sob a forma da confiança, da coragem, do humor, da astúcia, da firmeza, e agem de longe, do fundo dos tempos. Elas questionarão sempre cada vitória dos dominadores.
\end{abstract}

Entre "essas coisas espirituais e refinadas" que a luta de classes traz à tona, colocaria sem temor a arte (em particular, a poesia). Para lidar com o camaleão inimigo que "espreita", o poeta tem de se transformar num camaleão que "espia", com humor e astúcia. Nem toda testemunha se veste de herói, de mártir. Basta a dor de fingir-se pedra quando o inimigo espreita. Uma dor disfarçada de esperteza. Uma dor dourada, feliz nem "verde, cinza ou marrom".

Fique, pois, do debate uma ideia nuclear: a figura do camaleão no artigo de Gaspari se refere às artimanhas que o regime ditatorial teve de engenhar para se perpetuar no poder, a balas e atos institucionais, e dele se retirar, duas décadas após o golpe, sem que houvesse maiores abalos nem caça aos culpados: o camaleão-Estado venceu.

A figura do camaleão no poema de Chacal aponta para um tipo de resistência pouco considerada nos ensaios crítico-teóricos acerca da poesia marginal: o disfarce, como resistência. Com facilidade, esse disfarce pode se confundir com "alienação" ou "covardia", ao não reconhecer ou não enfrentar o inimigo. Mas fingir-se de pedra na

\footnotetext{
${ }^{18}$ Exercício crítico, por exemplo, que Fernanda Teixeira de Medeiros fez em "Play it again, marginais" (MEDEIROS, 1998, p.53-68) e que Vinicius Dantas não quis fazer em "A nova poesia brasileira e a poesia" (DANTAS, 1986, p.40-53).
} 
presença do inimigo é já, de algum modo, reconhecê-lo e enfrentá-lo. A arte do fingimento como tática de sobrevivência: o camaleão-Poeta também venceu.

A longa tirania do Estado brasileiro se fez camaleônica e fez com que tantos cidadãos, para sobreviverem, de modo semelhante, se transformassem. Outros tantos não quiseram, ou não puderam, adotar tal estratégia - e sucumbiram. Sem perpetuar a culpa de ter sobrevivido à barbárie, o poema de Chacal (um poema qualquer) pode sempre nos recordar que "assim como as flores dirigem sua corola para o sol, o passado, graças a um misterioso heliotropismo, tenta dirigir-se para o sol que se levanta no céu da história" (BENJAMIN, 1983, p.224). O tempo não para nem retorna, mas saber ler o passado pode impedir - ou dificultar - que flores murchem prematuramente. Se nada obstruir o encontro do "passado" com o "sol”, a história se fará, com certeza, mais digna, e não precisaremos mais temer o inimigo. Quando este utópico encontro se der, a alegria há de chegar e com ela poderemos - livres de dor, culpa e ressentimento - "dar um rolê por aí”.

\section{REFERÊNCIAS}

ADORNO, Th. W. Palestra sobre lírica e sociedade [1957]. In: Notas de

literatura I. Tradução e apresentação de Jorge M. B. de Almeida. São Paulo: Duas Cidades/Ed.34, 2003. p.65-89.

ARISTÓTELES. Poética. Tradução de Eudoro de Souza. São Paulo: Abril Cultural, 1984.

AUDEN, W. H. Notas sobre o cômico. In: A mão do artista. Tradução de José Roberto O'Shea. São Paulo: Siciliano, 1993.

BAKHTIN, M. A cultura popular na Idade Média e no Renascimento: o contexto de François Rabelais. Tradução de Yara Frateschi Vieira. 4.ed. São Paulo: Hucitec; Brasília: UnB, 1999.

BARTHES, R. O prazer do texto. Tradução de J. Guinzburg. São Paulo: Perspectiva, 1977.

BENJAMIN, W. Sobre o conceito da história. In: Magia e técnica, arte e política - ensaios sobre literatura e história da cultura. 5.ed. Tradução de Sergio Paulo Rouanet. São Paulo: Brasiliense, 1983 (Obras escolhidas - vol.1). p.222-232.

BERGSON, H. O riso. 2.ed. Tradução de Nathanael C. Caixeiro. Rio de Janeiro: J. Zahar, 1983. 
CACASO. Não quero prosa. Campinas, SP: UNICAMP; Rio de Janeiro: UFRJ, 1997.

CHACAL. Belvedere. São Paulo: Cosac \& Naify; Rio de Janeiro: 7Letras, 2007. Muito prazer. Rio de Janeiro: Sette Letras, 1997.

DALCASTAGNÈ, R. O espaço da dor: o regime de 64 no romance brasileiro. Brasília: UnB, 1996.

DANTAS, V. A nova poesia brasileira e a poesia. Novos Estudos CEBRAP, São Paulo, n.16, p.40-53, dez.1986.

FAUSTO, B. História concisa do Brasil. São Paulo: EDUSP, 2002.

FELMAN, S. Educação e crise, ou as vicissitudes do ensinar. In: SELIGMANNSILVA, M.; NESTROVSKI, A. (Org.). Catástrofe e representação: ensaios. São Paulo: Escuta, 2000. p.13-71.

FREUD, S. Obras completas. Tradução de Jayme Salomão. Rio de Janeiro: Imago, 1977 (Vol. VIII).

GAGNEBIN, J.-M. Palavras para Hurbinek. In: SELIGMANN-SILVA, M.;

NESTROVSKI, A. (Org.). Catástrofe e representação: ensaios. São Paulo: Escuta, 2000. p.99-110.

GASPARI, E. Alice e o camaleão. In: GASPARI, E.; HOLLANDA, H. B. de; VENTURA, Z. Cultura em trânsito: da repressão à abertura. Rio de Janeiro: Aeroplano, 2000. p.12-37.

HOLLANDA, H. B. de. Impressões de viagem: CPC, vanguarda e desbunde 19601970. 3.ed. Rio de Janeiro: Rocco, 1992.

LEMINSKI, P. Vida - Cruz e Sousa, Bashô, Jesus, Trótski. Porto Alegre: Sulina, 1990.

MARCO, V. de. A literatura de testemunho e a violência de Estado. Disponível em http://www.scielo.br/scielo.php?pid=S0102. Acesso em 22 agosto 2005.

MEDEIROS, F. T. de. Play it again, marginais. In: PEDROSA, C.; MATOS, C.; NASCIMENTO, E. (Org.). Poesia hoje. Niterói, RJ: EDUFF, 1998. p.53-68.

MENEZES, E. D. B. de. Revista de Cultura Vozes, ano 68, vol. LXVIII, n.1, p.10-18, jan.-fev. 74.

MORICONI, I. (Org.). Os cem melhores contos brasileiros do século. Rio de Janeiro: Objetiva, 2000.

NEVES, L. F. B. A ideologia da seriedade. Revista de Cultura Vozes, ano 68, vol. LXVIII, n.1, p.32-41, jan.-fev. 74.

NIETZSCHE, F. Assim falou Zaratustra - um livro para todos e para ninguém. Tradução de Mário da Silva. Rio de Janeiro: Bertrand Brasil, 1995. 
NUNES, B. O riso modernista. Terceira margem, Rio de Janeiro, a.1, n.1, p.28-38, 1993.

PROPP, V. Comicidade e riso. Tradução de Aurora Fornoni Bernardini e Homero Freitas de Andrade. São Paulo: Ática, 1992.

SALGUEIRO, W. Lira à brasileira: erótica, poética, política. Vitória: EDUFES, 2007. SELIGMANN-SILVA, M. (Org.). História, memória, literatura: o testemunho na era das catástrofes. Campinas, SP: UNICAMP, 2003.

A história como trauma. In: SELIGMANN-SILVA, M.; NESTROVSKI, A.

(Org.). Catástrofe e representação: ensaios. São Paulo: Escuta, 2000. p.73-98.

Artigo recebido em 31/08/2010

Aceito para publicação em 01/11/2010 